\title{
Comparison of the follicular size of the mosquito, Culex tritaeniorhynchus summorosus Dyar, collected by the pig and dry ice baited traps
}

\author{
Takaaki YAJIMA \\ Biological Institute, Faculty of Science, Tōhoku Cnizersity, Sendai 980
}

(Received: August 18, 1975

\begin{abstract}
Under an assumption that the age of the population of female mosquito, Culex tritaeniorhynchus summorosus Dyar, captured in the pig baited traps will be older than that in the dry ice baited traps, the dimensional difference of the $\mathrm{Ib}$ follicular stage was compared between two populations. The follicular size of nulliparous and monoparous sac-like females, in the dilatation stages of a population in a pig baited trap was significantly larger than that of a population in a dry ice baited trap. However, the $\mathrm{Ib}$ follicular stage in each physiological age of the population in the pig baited trap was not significantly different in size between the specimens collected in the earlier and the latter half of the night, and such tendency was also recognized in the case of the population in the dry ice baited trap.
\end{abstract}

The dimensional change of the mosquito follicles in the course of the ovarian development and the seasonal change of the follicular size have been studied by many authors (Yamaguchi, 1966; Taketomi, 1967; Oda, 1968). However, the reaction of female mosquitoes to an attractant in relation to the dimensional difference of the follicular size in the same ovarian stage seems to have been ignored.

The author has studied on the nocturnal blood feeding activity of female mosquitoes, Culex tritaeniorhynchus summorosus Dyar, in relation to the physiological age (Yajima et al., 1971); and also on the daily changes of the number of female mosquitoes emerged and oviposited, and on the ovarian changes following emergence, blood feeding and oviposition (Yajima, 1973). From the results of these studies, it was suggested that, though

矢島孝昭：東北大学理学部生物学教室（于 980 似 台市荒巻字青葉)

* Present address: Department of Biology, College of Liberal Arts, Kanazawa Lniversity, Kanazawa 920 mosquito populations caught in a pig baited trap and in a dry ice baited trap were both in the same Ib follicular stage, the former population seemed to be older than the latter (Yajima, 1974).

In the present study, the dimensional difference of the Ib follicular stage between the populations caught in these two different types of traps was compared seasonally in both the nulliparous and the monoparous females in order to ensure the above assumption.

\section{MATERIAL AND METHOdS}

The present experiments were done in the rural area of Natori City, Miyagi Prefecture, northern part of Japan. Female mosquitoes, Culex tritaeniorhynchus summorosus, were collected by two kinds of traps, which were dericed by Katō et al. (1966). Namely, to trap the mosquitoes invading to a pig shed two window traps were set on the east and the south side of the shed located on an open border between a paddy field and a crop field, and a dry ice baited trap was 
set in a paddy field about $200 \mathrm{~m}$ apart from the pig shed. As both traps were located near the paddy field, the distance from the emergence or the oviposition site of the mosquitoes to those traps seems not to be different. The mosquitoes were collected twice a night, in the earlier half of the night $(18: 00-0: 00)$ and in the latter half of the night $(0: 00-6: 00)$, on every Wednesday, Thursday and Friday from late May to early October in 1968. The mosquitoes collected by each trap were immediately killed with etyl ether and separately preserved in a small glass tube with a cork stopper. The samples were kept in a stockerat about $-20^{\circ} \mathrm{C}$ until the decision of the physiological age and the measurement of the Ib follicular size were made. In this case, the existence of blood in the stomach was observed. And, even if the females were in the Ib stage, the blood-fed ones were excluded from the specimens to compare the $\mathrm{Ib}$ follicular size between two populations.

The decision of the physiological age was done by the method reported by Detinova (1962). Each ovarian stage was classified according to Mer and Macan's method (Clements, 1963) with a necessary modification. Namely, No: the follicle in newly emerged females is not distinguishable from the germarium. Ia: the follicle is spherical and the oocyte is not differentiated from the nurse cells. Ib: the follicle is oval and consists of an oocyte and seven nurse cells surrounded by a distinct follicular epithelium. II a : a few very fine yolk granules appear around the oocyte nucleus. II b : the coarse yolk granules appear around the oocyte nucleus, the follicle grows and the oocyte takes up about half of the follicle. IIIa: the oocyte cytoplasm is cloudy with yolk granules and the oocyte occupies about half to two-thirds of the follicle. III b the yolk obscures the oocyte nucleus and the oocyte occupies two-thirds to three-quarters of the follicle. IVa: the follicle starts to elongate and the nurse cells occupy only about onetenth of it. IVb: the follicle assumes the shape of the mature egg. $\mathrm{V}$ : the micropyle cup is visible and the egg becomes ready for laying.

Besides, the pedicelian condition of the parous females was divided into three stages of A, B and C according to Corbet (1964). Namely, A is the sac-like stage, B the half contraction stage and $\mathrm{C}$ the dilatation stage, respectively.

Almost all of female mosquitoes collected by the pig and the dry ice baited traps were in the Ib stage (Yajima et al., 1971) and, in general, the follicles did not develop beyond the II a stage until the blood feeding (Yajima, 1973). Therefore, in order to know the change of the follicular size throughout the ovarian development, the measurement of the follicular size was done using the laboratory reared females and the freshly blood-fed ones which were collected in a pig shed. The former females which were used to know the change of the follicular size following emergence were supplied with a concentration of 5 per cent sucrose and the latter females which were used to determine the ovarian development following a blood meal were kept in the laboratory only with water. The laboratory conditions were as follows. The temperature was about $25^{\circ} \mathrm{C}$, the relative humidity was approximately 100 per cent and the light cycled $14 \mathrm{hr}$ light and $10 \mathrm{hr}$ dark by switching the lamp on and off at 5:00 and at 19:00. Each follicular size was measured with a micrometer in a microscope of 50 to $200 \times$ magnification.

\section{RESUlTS}

Change of the follicular size throughout the ovarian development and the relation between the length and the width of the follicles in the Ib stage

Before going into the comparison of the dimensional difference of the $\mathrm{Ib}$ follicular stage between the populations captured by two types of traps, the change of the follicular size throughout the ovarian development in blood-fed females was examined. The length and the width of follicles in each ovarian stage (No to $\mathrm{V}$ stage) are shown in Fig. 1. Except for the IVb and $\mathrm{V}$ stage, the length and the width increased gradually. In the IVb stage, the width became smaller than that of the IVa stage, but the length increased rapidly, and thus, the shape of 


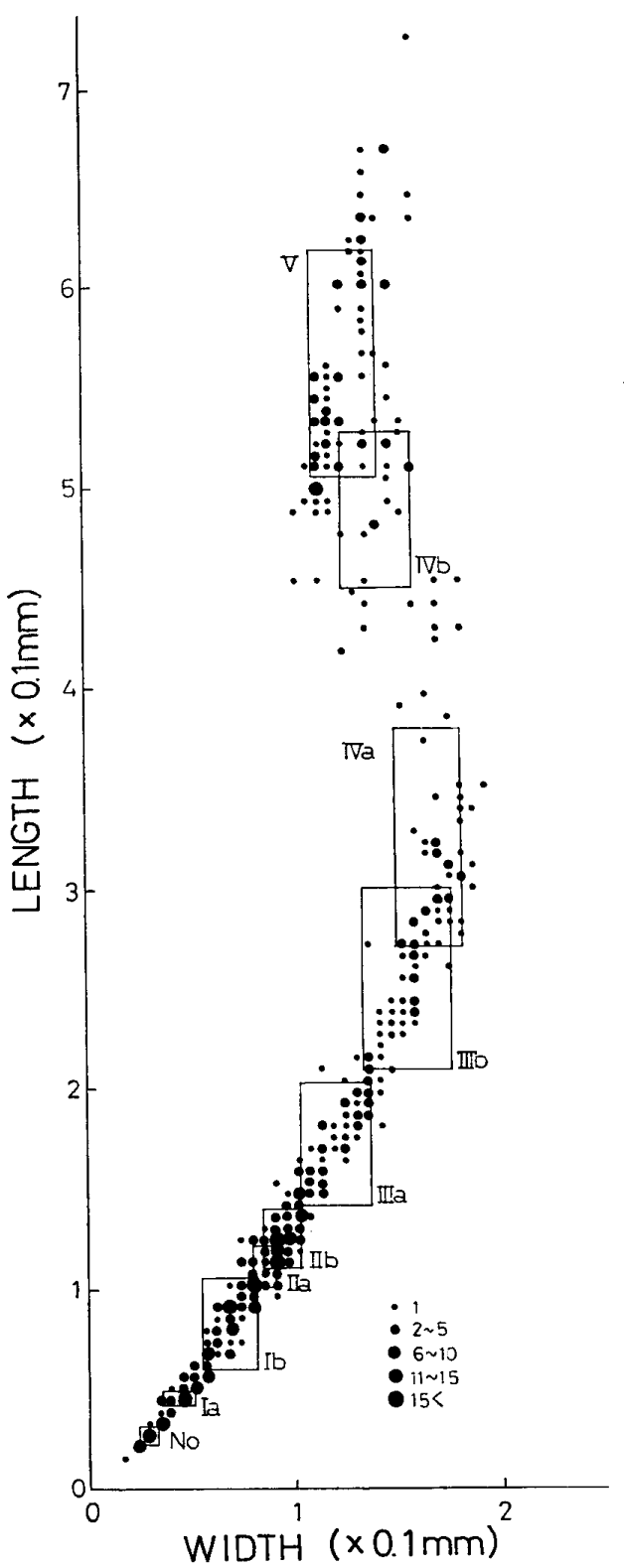

Fig. 1 Relationship between the length and the width of follicles in bloodfed females of Culex tritaeniorhynchus summorosus

Rectangle shows the fiducial limit in 95 per cent reliability of the length and width of each follicular size.

the follicles became slender in the $\mathrm{IVb}$ and $\mathrm{V}$ stage. The mean length and width of the follicles of each ovarian stage were as follows: No stage $0.028 \times 0.028$, Ia $0.046 \times$ 0.043 , Ib $0.084 \times 0.068$, II a $0.112 \times 0.084$, II b $0.123 \times 0.094$, III a $0.172 \times 0.120$, III b $0.255 \times$ 0.155 , IVa $0.326 \times 0.162$, IVb $0.489 \times 0.142$ and $\mathrm{V} 0.562 \times 0.126 \mathrm{~mm}$, respectively.

The follicular sizes of the I b stage in the populations in the pig and the dry ice baited traps are shown collectively in Fig. 2. The

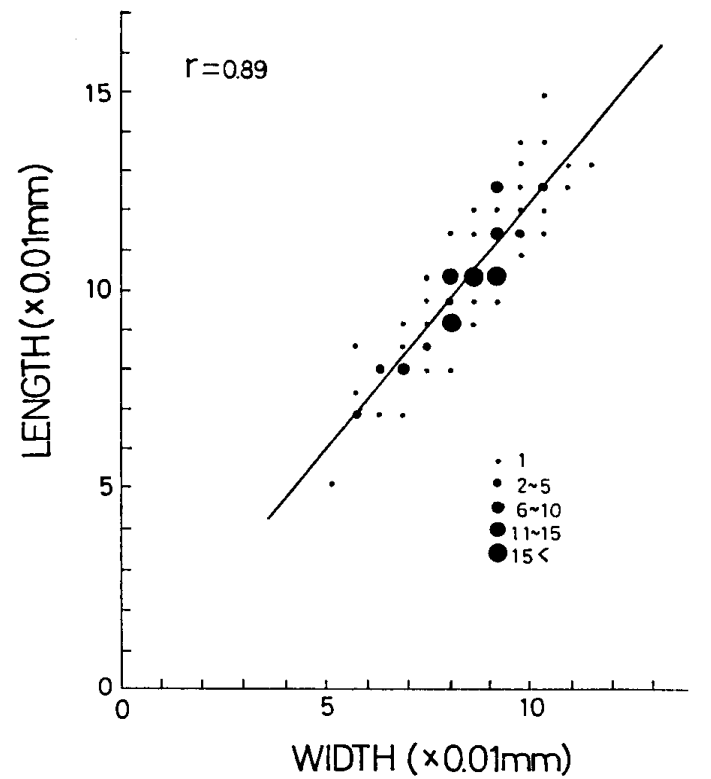

Fig. 2 Relationship between the length and the width of follicles in the Ib stage in Culex tritaeniorhynchus summorosus collected by the dry ice and the pig baited traps

$r$ : correlation coeffcient.

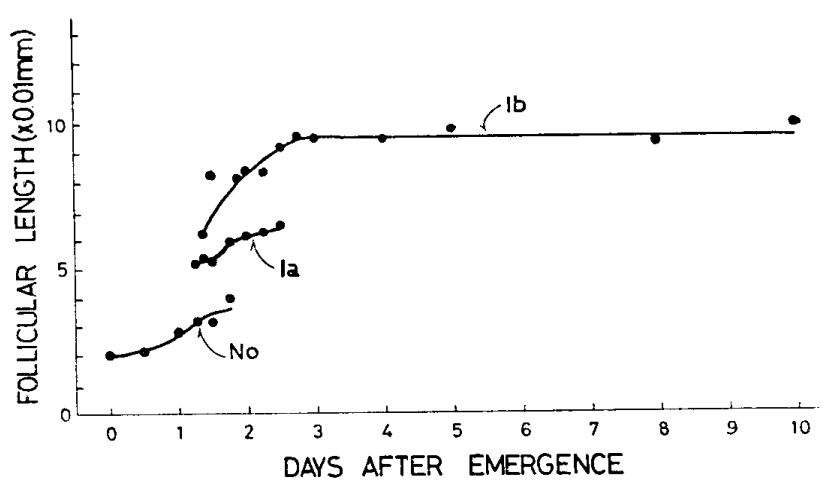

Fig. 3 Change in the follicular length of newly emerged females of Culex tritaeniorhynchus summorosus in each ovarian stage after emergence Dark circles show the mean follicular length in each ovarian stage.

relation between the length $(Y)$ and the width $(X)$ was expressed by a formula $Y=$ $1.24 X-0.17$, having a correlation coefficient ( $r$ ) of 0.89 .

Figure 3 shows the change of the follicular length of unengorged females in relation to the ovarian development following emergence. The number of females used for decision of the ovarian stage and the follicular length ranged from five to ten individuals at each measurement. According to Fig. 3, the average of the follicular length 
became rapidly larger from the No to $\mathrm{Ib}$ stage with time. The follicles which stayed in the $I b$ stage ceased to lengthen and attained to a certain dimension within one or two days.

Comparison of the follicular size of the Ib stage between the pig and the dry ice baited trap populations

The parous females in the half contraction stage (B) were very few. Therefore, in this paper, the comparison of the I b follicular size of parous females between the populations in the pig and the dry ice baited trap was done with the monoparous ones in the sac-like stage (A) and in the dilatation stage (C) which occupied about 90 per cent among the parous ones.

Figures 4, 5 and 6 show the results of the seasonal change of the $\mathrm{I} b$ follicular size of nulliparous and monoparous females collected by the pig and the dry ice baited traps.

In the case of the nulliparous females (Fig. 4), except for the fourth week of June

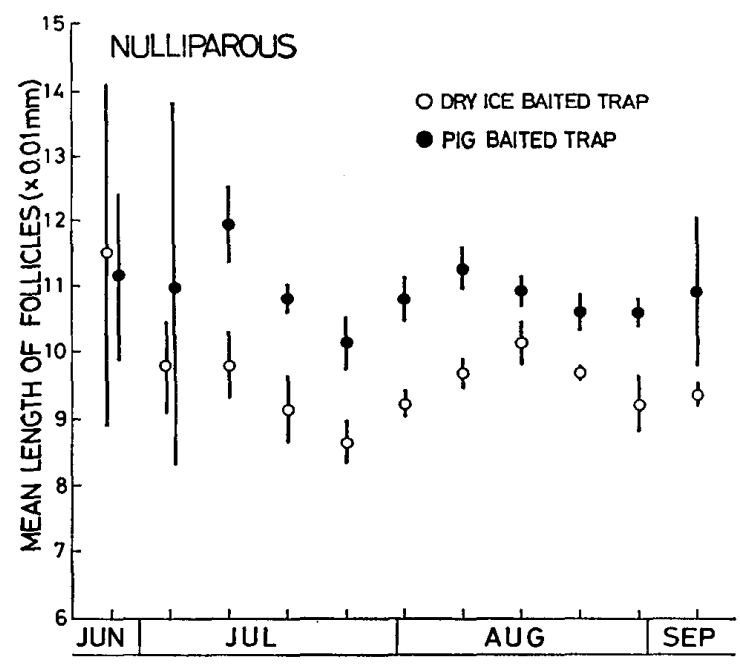

Fig. 4 Seasonal change in the Ib follicular size of nulliparous females of Culex tritaeniorhynchus summorosus collected by the dry ice and the pig baited traps

Vertical lines show the fiducial limit in 95 per cent reliability.

and the first week of July when a small number of females were collected, the follicular size of the population in the pig baited trap was significantly longer than that in the dry ice baited trap. The results in the monoparous females in the stages of

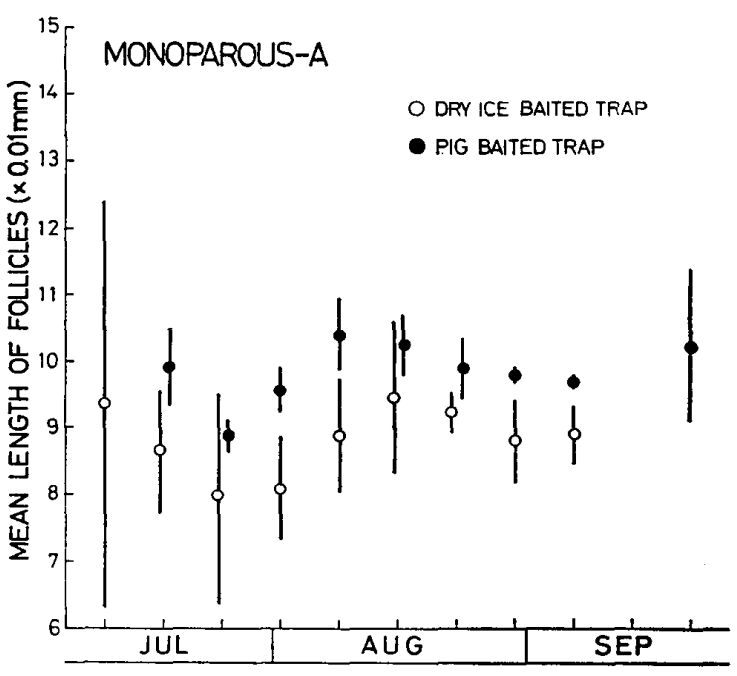

Fig. 5 Seasonal change in the Ib follicular size of monoparous females of Culex tritaeniorhynchus summorosus in the sac-like stage collected by the dry ice and the pig baited traps

Vertical lines show the fiducial limit in 95 per cent reliability.

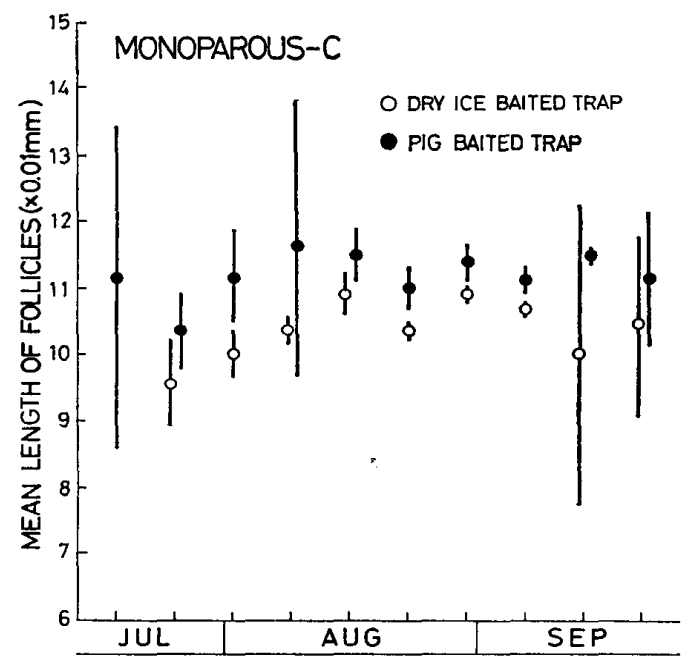

Fig. 6 Seasonal change in the Ib follicular size of monoparous females of Culex tritaeniorhynchus summorosus in the dilatation stage collected by the dry ice and the pig baited traps

Vertical lines show the fiducial limit in 95 per cent reliability.

$\mathrm{A}$ and $\mathrm{C}$ were similar to the nulliparous ones, but the difference of the follicular size between two populations was not so notable (Figs. 5 and 6). It seemed also that the seasonal change of the Ib follicular size in each physiological age showed a similar pattern. Namely, the follicular size decreased gradually until the fourth week of July, 


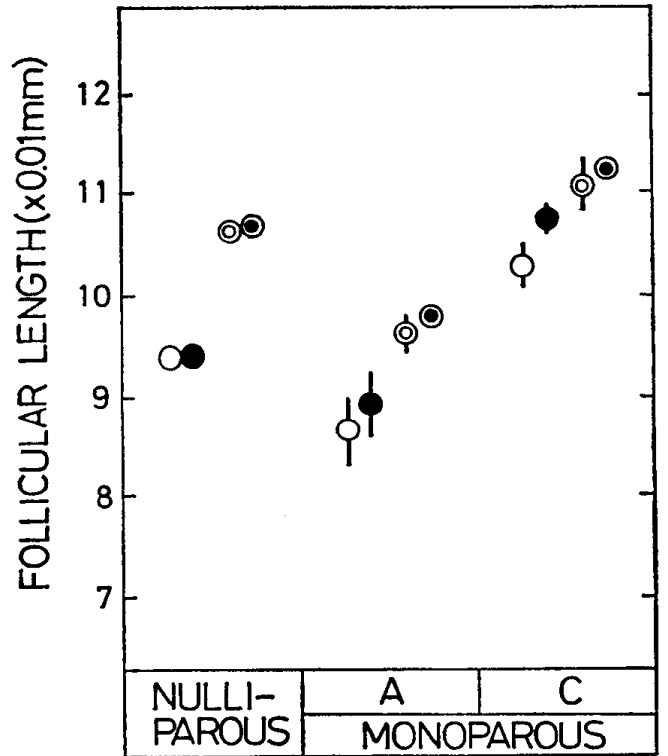

Fig. 7 Comparison of the Ib follicular size of nulliparous and monoparous females in the sac-like stage (A) and in the dilatation stage $\mathrm{C}$ ) in Culex tritaeniorhynchus summorosus All of mosquitoes dissected throughout the survey period were pooled. Vertical lines show the fiducial limit in 95 per cent reliability.

$O$ : females collected by the dry ice baited trap in the earlier half of the night.

- : females collected by the dry ice baited trap in the latter half of the night.

(-) : females collected by the pig baited trap in the earlier half of the night.

O : females collected by the pig baited trap in the latter half of the night.

then it increased to the second or the third week of August and decreased again thereafter.

The difference of the Ib follicular size in each physiological age was compared as a whole between the populations in the pig and the dry ice baited traps for each of the earlier and the latter half of the night collections (Fig. 7). Although as shown in Fig. 7, the Ib follicular size of the population in the pig baited trap was longer than that of the population in the dry ice baited trap in every physiological age, no dimensional difference between the earlier and the latter half of the night collections was especially recognized in nulliparous females. The mean length of the Ib follicles of nulliparous females $(0)$, monoparous ones in the sac like stage (A) and in the dilatation stage
(C) of the population in the pig baited trap were $0.108,0.093$ and $0.112 \mathrm{~mm}$, and also those of the population in the dry ice baited trap were $0.094,0.088$ and $0.106 \mathrm{~mm}$, respectively. Thus, the Ib follicular size in each physiological age of the population in the pig baited trap was significantly larger than that of the population in the dry ice baited trap.

\section{Discussion}

Followings could be concluded from this study that the Ib follicles of newly emerged female mosquitoes became larger with time after emergence and the follicles which stayed in the Ib stage ceased to lengthen and attained to a certain dimension. The Ib follicular sizes of nulliparous females, monoparous ones in the sac-like stage and in the dilatation stage of the mosquitoes captured in a pig baited trap were significantly larger than those of the mosquitoes in a dry ice baited trap. However, the Ib follicular size in nulliparous females was not significantly different between the earlier and the latter half of the night collections both among the population caught in the pig or the dry ice baited trap.

It could be also concluded that the reason why the Ib follicular size in each physiological age of the population in the pig baited trap was larger than that of the population in the dry ice baited trap seemed not to be explained by the consideration that the population in the pig baited trap was sampled at farther place apart from the emergence or the oviposition site compared to the population in the dry ice baited trap. Thus, the dimensional difference of the Ib follicular stage between two populations captured by two different types of traps might be due to the difference in the developement of the Ib follicles with time. In other words, the population in the dry ice baited trap might be younger than that in the pig baited trap. The dimensional difference of the $\mathrm{Ib}$ follicular stage between the populations in the dry ice and the pig baited traps may suggest that the former population might have lower blood feeding activity than the latter which comes to the 
pig to feed blood. Such problem will be dealt in a next paper.

Furthermore, there was a discrepancy in the Ib follicular size in nulliparous females between the results obtained in the laboratory and field observations. In the laboratory experiment, the follicles in the $\mathrm{Ib}$ stage were always less than $0.1 \mathrm{~mm}$ in length. On the contrary, most of the Ib follicles of mosquitoes collected in nature, especially those captured by the pig baited trap, were over $0.1 \mathrm{~mm}$. Such discrepancy might be caused by many factors as temperature, light condition, source of food, and so forth. Further examination will be necessary to solve this problem.

\section{ACKNOWLEDGEMENTS}

The author wishes to express his gratitude to Dr. Mutsuo Katō, President of the Tōhoku University, for his frequent, stimulating and helpful discussion. Thanks are also due to Dr. Moritaka Nishihira of the University of the Rhukyus for his critical suggestions.

\section{REFERENCES}

Clements, A. N. (1963): The physiology of mosquitoes. 393 pp., Pergamon Press, London.

Corbet, P. S. (1964) : The ovarian condition of certain sylvan mosquitoes in Uganda (Diptera, Culicidae). Bull. Ent. Res., 55 : 357-382.

Detinova, T. S. (1962): Age-grouping methods in Diptera of medical importance. $216 \mathrm{pp}$, WHO Monograph 47, Geneve.

Katō, M., T. Ishii, T. Watanabe and S. Yoshida (1966): A new dry ice baited trap for collecting mosquitoes. Jap. J. Sanit. Zool., 17 : 83-88.

Oda, T. (1968): Studies on the follicular development and overwintering of the house mosquito, Culex pipiens pallens in Nagasaki area. Tropical Medicine, 10 : 195-216.

Taketomi, M. (1967): Ovariole and age changes in Anopheles sinensis Wiedemann, with special reference to the relation to temperature and season. Endem. Dis. Bull. Nagasaki, 8 : 170190.

Yajima, T., S. Yoshida and T. Watanabe (1971): Ecological studies on the population of adult mosquito, Culex tritaeniorhynchus summorosus Dyar: The diurnal activity in relation to the physiological age. Jap. J. Ecol., 21 : 204-214.
Yajima, T. (1973): Ecological studies on the gonotrophic cycle of the mosquito, Culex tritaeniorhynchus summorosus Dyar, in relation to the ovarian condition. Sci. Rep. Tohoku Univ., Ser. IV (Biol.), 36 : 241-253.

Yajima, T. (1974): Influence of the ovarian condition on the diurnal activity pattern of the mosquito, Culex tritaeniorhynchus summorosus Dyar. Ecol. Rev., 18 : 57-64.

Yamaguchi, N. (1966) : Comparative studies on Culex pipiens group of Japan. 3. Some observations on follicular development, oviposition and mating activities in autogenous form of Culex pipiens in Japan. Jap. J. Sanit. Zool., $17: 98-107$. (in Japanese with English summary).

\section{摘 要}

豚トラップとドライアイス・トラップ で採集されたコガタアカイエカ の濾胞の大きさの比較

蚊は, 小卯巣の形態変化から生理的年令が判り，栄養 生殖サイクルのどの位置にあるかを知ることができる。 このことは，用いた採集方法を併せ考えると，蚊の生活 史や，それと関連した活動性を解明することも可能であ ろう.

著者は先に, コガタアカイエカは I b 期の濾胞ステー ジで吸血するとはいえ，同じ I b 期にあっても, ドライ アイス・トラップ個体群よりも豚トラップ個体群の方が より老令であり，吸血活動性も異なることを推論した. このことを確かめるために，本報では豚トラップ個体群 とドライアイス・トラップ個体群について, 各生理的年 令にある I b 期の濾胞の大きさを比較検討することを試 みた。その結果,

1. I b 期の濾胞の大きさには, 生理的年令および個 体群の違いに関係なく, ある一定の季節変動パターンが 認められた。

2.末経産および 1 回産卵のうち柄部の収縮状態が $\mathrm{A}$ 期と C 期にある I b 期の濾胞の大きさは, 豚トラップ個 体群の方がドライアイス・トラップ個体群よりも，それ ぞれ大きかった。

3. 同じ生理的年令にある $\mathrm{I} b$ 期の濾胞の大きさを 豚トラップ個体群とドライアイス・トラップ個体群別に 前半夜と後半夜との間で比較したところ, 有意な差は認 められず, このことは，未経産蚊群で顕著であった。

4. I b 期の濾胞は, 時間の経過とともに大きさを増 すが，ある大きさに達すると，吸血するまで一般に I b 期に停まると同時に, 濾胞の大きさも一定であった.

以上の結果から，同じ生理的年令の I b 期にあって も, 豚トラップ個体群の方が, ドライアイス・トラップ 個体群よりも，より老令なものであることが判明した， 